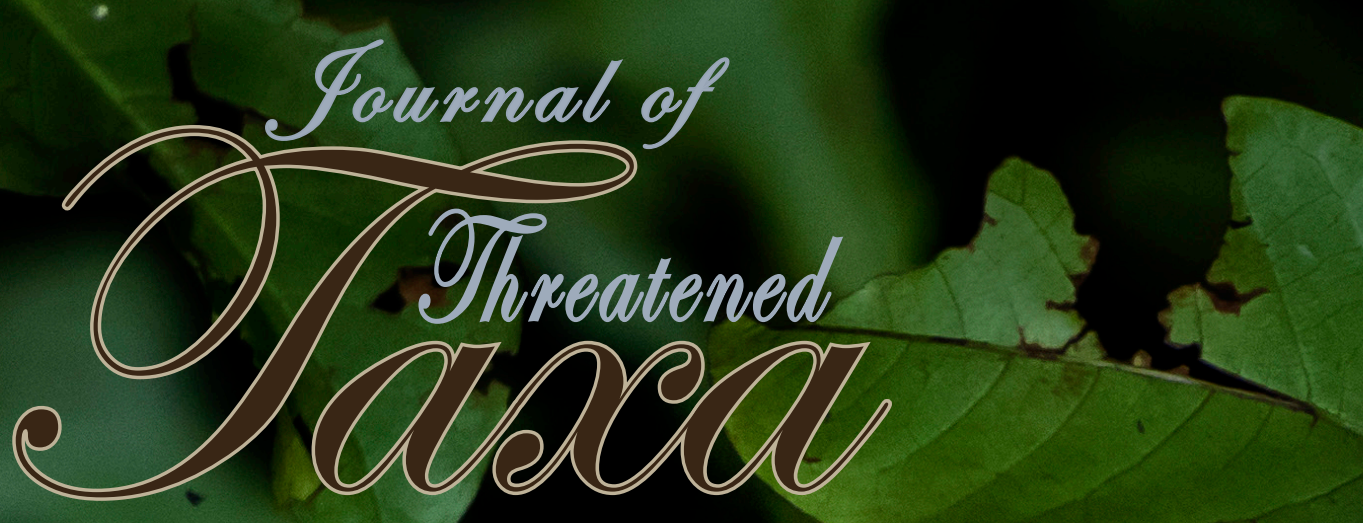

Building exidence for conservation glabally

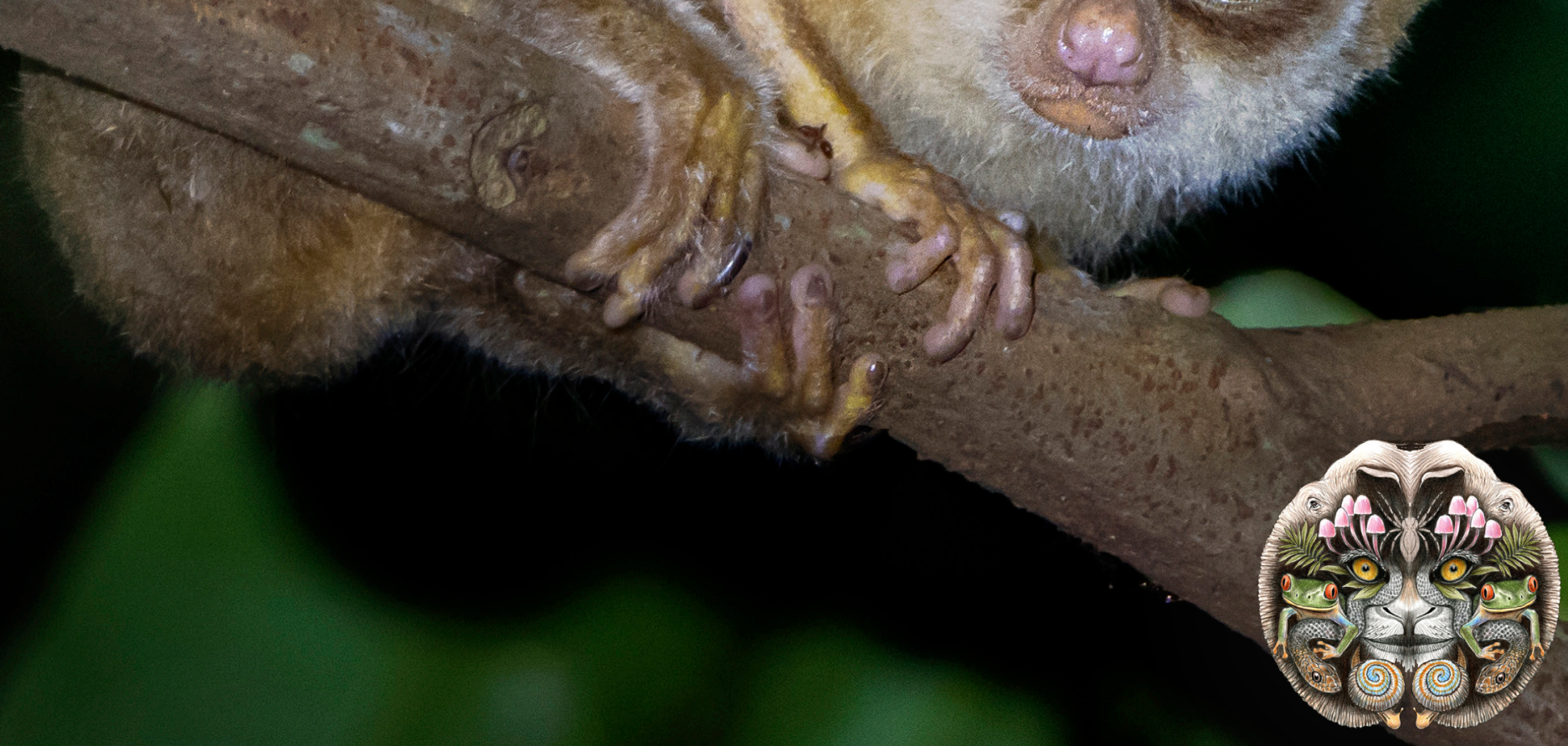

Open Access

$10.11609 /$ jott.2021.13.010.19431-19614 creven.threatenedtaxa.arg

26 September 2021 (Online \& Print) Val. 13 | Na. 11 | Pages: 19431-19674 


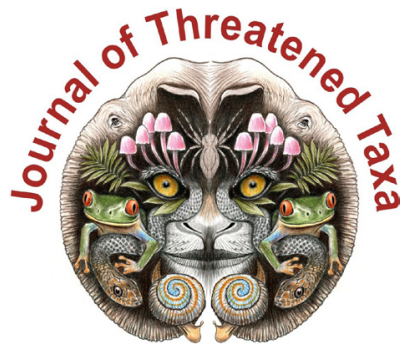

ISSN 0974-7907 (Online); ISSN $0974-7893$ (Print)

Publisher

Host

Wildlife Information Liaison Development Society

www.wild.zooreach.org

Zoo Outreach Organization www.zooreach.org

No. 12, Thiruvannamalai Nagar, Saravanampatti - Kalapatti Road, Saravanampatti, Coimbatore, Tamil Nadu 641035, India

Ph: +91 9385339863 | www.threatenedtaxa.org

Email: sanjay@threatenedtaxa.org

EDITORS

\section{Founder \& Chief Editor}

Dr. Sanjay Molur

Wildlife Information Liaison Development (WILD) Society \& Zoo Outreach Organization (ZOO)

12 Thiruvannamalai Nagar, Saravanampatti, Coimbatore, Tamil Nadu 641035, India

\section{Deputy Chief Edito}

Dr. Neelesh Dahanukar

Noida, Uttar Pradesh, India

\section{Managing Editor}

Mr. B. Ravichandran, WILD/ZOO, Coimbatore, India

\section{Associate Editors}

Dr. Mandar Paingankar, Government Science College Gadchiroli, Maharashtra 442605, India

Dr. Ulrike Streicher, Wildlife Veterinarian, Eugene, Oregon, USA

Ms. Priyanka Iyer, ZOO/WILD, Coimbatore, Tamil Nadu 641035, India

Dr. B. A. Daniel, $200 / \mathrm{WILD}$, Coimbatore, Tamil Nadu 641035, India

\section{Editorial Board}

Dr. Russel Mittermeier

Executive Vice Chair, Conservation International, Arlington, Virginia 22202, USA

\section{Prof. Mewa Singh Ph.D., FASc, FNA, FNASc, FNAPsy}

Ramanna Fellow and Life-Long Distinguished Professor, Biopsychology Laboratory, and Institute of Excellence, University of Mysore, Mysuru, Karnataka 570006, India; Honorary Professor, Jawaharlal Nehru Centre for Advanced Scientific Research, Bangalore; and Adjunct Professor, National Institute of Advanced Studies, Bangalore

\section{Stephen D. Nash}

Scientific Illustrator, Conservation International, Dept. of Anatomical Sciences, Health Sciences Center, T-8, Room 045, Stony Brook University, Stony Brook, NY 11794-8081, USA

\section{Dr. Fred Pluthero}

Toronto, Canada

\section{Dr. Priya Davidar}

Sigur Nature Trust, Chadapatti, Mavinhalla PO, Nilgiris, Tamil Nadu 643223, India

\section{Dr. Martin Fisher}

Senior Associate Professor, Battcock Centre for Experimental Astrophysics, Cavendish

Laboratory, JJ Thomson Avenue, Cambridge CB3 OHE, UK

\section{Dr. John Fellowe}

Honorary Assistant Professor, The Kadoorie Institute, 8/F, T.T. Tsui Building, The University of Hong Kong, Pokfulam Road, Hong Kong

\section{Prof. Dr. Mirco Solé}

Universidade Estadual de Santa Cruz, Departamento de Ciências Biológicas, Vice-coordenado do Programa de Pós-Graduação em Zoologia, Rodovia Ilhéus/Itabuna, Km 16 (45662-000)

Salobrinho, Ilhéus - Bahia - Brasil

\section{Dr. Rajeev Raghavan}

Professor of Taxonomy, Kerala University of Fisheries \& Ocean Studies, Kochi, Kerala, India

\section{English Editors}

Mrs. Mira Bhojwani, Pune, India

Dr. Fred Pluthero, Toronto, Canad

Mr. P. Ilangovan, Chennai, India

Web Maintenance

Mrs. Latha G. Ravikumar, ZOO/WILD, Coimbatore, India

\section{Typesetting}

Mr. Arul Jagadish, ZOO, Coimbatore, India

Mrs. Radhika, ZOO, Coimbatore, India

Mrs. Geetha, ZOO, Coimbatore India

\section{Fundraising/Communications}

Mrs. Payal B. Molur, Coimbatore, India

Subject Editors 2018-2020

Fungi

Dr. B. Shivaraju, Bengaluru, Karnataka, India

Dr. R.K. Verma, Tropical Forest Research Institute, Jabalpur, India

Dr. Vatsavaya S. Raju, Kakatiay University, Warangal, Andhra Pradesh, India

Dr. M. Krishnappa, Jnana Sahyadri, Kuvempu University, Shimoga, Karnataka, India

Dr. K.R. Sridhar, Mangalore University, Mangalagangotri, Mangalore, Karnataka, India

Dr. Gunjan Biswas, Vidyasagar University, Midnapore, West Bengal, India

Plants

Dr. G.P. Sinha, Botanical Survey of India, Allahabad, India

Dr. N.P. Balakrishnan, Ret. Joint Director, BSI, Coimbatore, India

Dr. Shonil Bhagwat, Open University and University of Oxford, UK

Prof. D.J. Bhat, Retd. Professor, Goa University, Goa, India

Dr. Ferdinando Boero, Università del Salento, Lecce, Italy

Dr. Dale R. Calder, Royal Ontaro Museum, Toronto, Ontario, Canada

Dr. Cleofas Cervancia, Univ. of Philippines Los Baños College Laguna, Philippines

Dr. F.B. Vincent Florens, University of Mauritius, Mauritius

Dr. Merlin Franco, Curtin University, Malaysia

Dr. V. Irudayaraj, St. Xavier's College, Palayamkottai, Tamil Nadu, India

Dr. B.S. Kholia, Botanical Survey of India, Gangtok, Sikkim, India

Dr. Pankaj Kumar, Kadoorie Farm and Botanic Garden Corporation, Hong Kong S.A.R., China

Dr. V. Sampath Kumar, Botanical Survey of India, Howrah, West Bengal, India

Dr. A.J. Solomon Raju, Andhra University, Visakhapatnam, India

Dr. Vijayasankar Raman, University of Mississippi, USA

Dr. B. Ravi Prasad Rao, Sri Krishnadevaraya University, Anantpur, India

Dr. K. Ravikumar, FRLHT, Bengaluru, Karnataka, India

Dr. Aparna Watve, Pune, Maharashtra, India

Dr. Qiang Liu, Xishuangbanna Tropical Botanical Garden, Yunnan, China

Dr. Noor Azhar Mohamed Shazili, Universiti Malaysia Terengganu, Kuala Terengganu, Malaysia Dr. M.K. Vasudeva Rao, Shiv Ranjani Housing Society, Pune, Maharashtra, India

Prof. A.J. Solomon Raju, Andhra University, Visakhapatnam, India

Dr. Mandar Datar, Agharkar Research Institute, Pune, Maharashtra, India

Dr. M.K. Janarthanam, Goa University, Goa, India

Dr. K. Karthigeyan, Botanical Survey of India, India

Dr. Errol Vela, University of Montpellier, Montpellier, France

Dr. P. Lakshminarasimhan, Botanical Survey of India, Howrah, India

Dr. Larry R. Noblick, Montgomery Botanical Center, Miami, USA

Dr. K. Haridasan, Pallavur, Palakkad District, Kerala, India

Dr. Analinda Manila-Fajard, University of the Philippines Los Banos, Laguna, Philippines

Dr. P.A. Sinu, Central University of Kerala, Kasaragod, Kerala, India

Dr. Afroz Alam, Banasthali Vidyapith (accredited A grade by NAAC), Rajasthan, India

Dr. K.P. Rajesh, Zamorin's Guruvayurappan College, GA College PO, Kozhikode, Kerala, India

Dr. David E. Boufford, Harvard University Herbaria, Cambridge, MA 02138-2020, USA

Dr. Ritesh Kumar Choudhary, Agharkar Research Institute, Pune, Maharashtra, India

Dr. Navendu Page, Wildlife Institute of India, Chandrabani, Dehradun, Uttarakhand, India

Invertebrates

Dr. R.K. Avasthi, Rohtak University, Haryana, India

Dr. D.B. Bastawade, Maharashtra, India

Dr. Partha Pratim Bhattacharjee, Tripura University, Suryamaninagar, India

Dr. Kailash Chandra, Zoological Survey of India, Jabalpur, Madhya Pradesh, India

Dr. Ansie Dippenaar-Schoeman, University of Pretoria, Queenswood, South Africa

Dr. Rory Dow, National Museum of natural History Naturalis, The Netherlands

Dr. Brian Fisher, California Academy of Sciences, USA

Dr. Richard Gallon, llandudno, North Wales, LL30 1UP

Dr. Hemant V. Ghate, Modern College, Pune, India

Dr. M. Monwar Hossain, Jahangirnagar University, Dhaka, Bangladesh

Mr. Jatishwor Singh Irungbam, Biology Centre CAS, Branišovská, Czech Republic

Dr. lan J. Kitching Natural History Museum, Cromwell Road, UK

Dr. George Mathew, Kerala Forest Research Institute, Peechi, India

Dr. John Noyes, Natural History Museum, London, UK

For Focus, Scope, Aims, and Policies, visit https://threatenedtaxa.org/index.php/JoTT/aims_scope
For Article Submission Guidelines, visit https://threatenedtaxa.org/index.php/JoTT/about/submissions
For Policies against Scientific Misconduct, visit https://threatenedtaxa.org/index.php/JoTT/policies_various 


\title{
The diel activity pattern of small carnivores of Western Ghats, India: a case study at Nelliampathies in Kerala, India
}

\author{
Devika Sanghamithra $^{1}$ (i) \& P.O. Nameer $^{2}$ (D) \\ 1,2 Centre for Wildlife Studies, College of Forestry, Kerala Agricultural University, Thrissur, Kerala 680656, India. \\ ${ }^{1}$ devikasanghamithra@gmail.com, ${ }^{2}$ nameer.po@kau.in (corresponding author)
}

\begin{abstract}
The diel activity pattern of small carnivores was studied using the camera trap technique at Nelliampathy Reserve Forest, Kerala, India. Six species of small carnivores were recorded during the study. These include Brown Palm Civet Paradoxurus jerdoni, Small Indian Civet Viverricula indica, Stripe-necked Mongoose Herpestes vitticollis, Brown Mongoose Herpestes fuscus, Nilgiri Marten Martes gwatkinsii, and Leopard Cat Prionailurus bengalensis. The maximum diel activity overlap was detected between the Brown Palm Civet and Small Indian Civet, while the activity overlap was minimal between the Stripe-necked Mongoose and Small Indian Civet.
\end{abstract}

Keywords: Activity overlap, camera traps, civet, endemism, marten, mongoose, otter, Palakkad district, small cat, southern India.

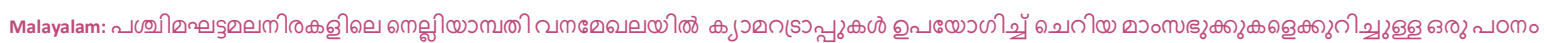

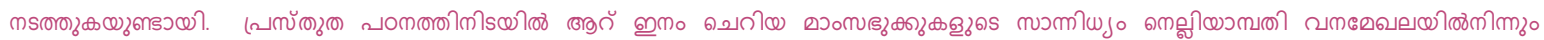

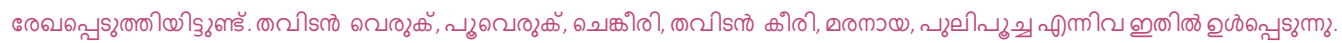

Copyright: (C) Sanghamithra \& Nameer 2021. Creative Commons Attribution 4.0 International License. JoTT allows unrestricted use, reproduction, and distribution of this article in any medium by providing adequate credit to the author(s) and the source of publication.

Funding: Kerala Agricultural University.

Competing interests: The authors declare no competing interests.

Author details: P.O. NAMEER is Professor and Head of Centre for Wildlife Studies, Kerala Agricultural University. His research interest include the taxonomy, biogeography and ecology of vertebrates of Western Ghats (except fishes). DEVIKA SANGHAMITHRA is the PhD scholar in the Department of Wildlife Sciences, Kerala Agricultural University, and this paper is an outcome of part of her PhD thesis.

Author contributions: Both the authors conceived and developed the idea, the field work was performed by the first author, both authors contributed equally in the data analysis and writing the manuscript.

Acknowledgements: We thank the principal chief conservator of forests and chief wildlife warden, Kerala Forest Department, for granting permission to conduct the study in the forests of Kerala (WL10-62639/2017 dated 01-08-2018). We thank the divisional forest officer, Nenmara Forest Division, the range forest officer and other staff of Nelliampathy forest range for providing logistics and support. We want to express our most sincere appreciation to Aswin K.S., Sachin K. Aravind, Sachin Krishna M.V., and Vivek K. for their help in the field. We thank Kerala Agricultural University for the financial assistance for the study. The first author is a recipient of the INSPIRE Senior Research Fellowship (IF160753) from the Department of Science and Technology, Government of India, and it is thankfully acknowledged. We are also grateful to three anonymous reviewers and the subject editor for their critical comments. 


\section{INTRODUCTION}

Small carnivores are medium-sized mammals belonging to the order Carnivora. There are 195 species of small carnivores globally belonging to 10 families (Wilson \& Mittermiere 2009). The Western Ghats has 14 species, out of which 13 are present in Kerala (Nameer 2015, 2020). Understanding the geographical and ecological distributions and abundance of each species is the foundation for effective management.

A study on the impact of various factors on habitat selection of Smooth-coated Otters Lutrogale perspicillata in Periyar Tiger Reserve (PTR) found that the otters showed affinity towards areas with less rocky and gently sloped banks with vegetation and adjoining streams (Anoop \& Hussain 2004). The central part of the L. perspicillata diet in PTR was fishes (96\%), among which tilapia was the primary food item during both lower and higher water levels in the lake (Anoop \& Hussain 2005). While comparing the abundance of small carnivores between an intact rainforest and adjoining forest fragments, it was observed that the intact forests have a higher abundance of small carnivores than the fragmented landscapes (Mudappa et al. 2007). Pools in the streams, particularly the second-order streams, were preferred by the Asian Small-clawed Otter Aonyx cinereus in the mountainous forests of Eravikulam National Park (Perincherry et al. 2011). Small carnivores of Mudumalai Tiger Reserve showed a negative relationship to the distance from the villages. Indian Grey Mongoose Herpestes edwardsii showed an affinity towards degraded forests, whereas Stripe-necked Mongoose $H$. vitticollis preferred subtropical evergreen and dry deciduous forests. Jungle Cat Felis chaus and Common Palm Civet Paradoxurous hermaphroditus preferred dry thorny and dry deciduous forests of the reserve. Open dry forests with moderate canopy were chosen by Ruddy Mongoose $H$. smithii and Small Indian Civet (Kalle et al. 2013a). The niche of Brown Mongoose $H$. fuscus fuscus was greatly influenced by temperature, rain and topography (Raman et al. 2020).

Brown Palm Civet $P$. jerdoni was believed to have distribution ranges from Kalakkad Mundanthurai Tiger Reserve, Tamil Nadu, to Bhagvan Mahaveer Wildlife Sanctuary in Goa. However, the distribution of Brown Palm Civet has extended further north of Goa up to Satara district of Maharashtra (Bhosale et al. 2013; Sayyed et al. 2019). Punjabi et al. (2014) have reported the northern extension of Stripe-necked Mongoose distribution from Maharashtra and Goa. Recent records of Brown Mongoose from Bilgiri Rangaswamy Temple Tiger Reserve points towards the southeast extension of the distribution of the species from its known range (Suthar et al. 2020).

Studies on the species richness of small carnivores from the Western Ghats reported varying species from the different regions. Kumara \& Singh (2006) and Kumara et al. (2014) reported 11 species of small carnivores from the forests of Karnataka. Parmbikulam Tiger Reserve reported 11 species, with Small Indian Civet and Common Palm Civet as the common ones (Sreehari \& Nameer 2016). The drier tracts of Wayanad Wildlife Sanctuary reported nine species, and similar to Parambikulam Tiger Reserve, Small Indian Civet was the most frequently sighted species at Wayanad WS. (Sreekumar \& Nameer 2018). The high-altitude landscape in Eravikulam National Park recorded nine species, and Jungle Cat and Leopard Cat were the common small carnivores (Nikhil $\&$ Nameer 2017). The rain forest landscape of Silent Valley National Park recorded only seven species. The Small Indian Civet was the most common small carnivore in the rainforest habitat (Sanghamithra \& Nameer 2018). Anil et al. (2018) reported on the social behaviour, feeding habits, and activity pattern of Martes gwatkinsii from the Pampadum Shola NP.

Diel activity pattern is one of the critical factors which determines the ecological niche of a species. It is also an essential tool for the co-living of the species (Gerber et al. 2012). Interspecific competition is reduced by the chronological separation between the species (Selvan et al. 2019). Variation in activity peaks was observed among sympatric species with similar activity (Su \& Sale 2007; Chen et al. 2009).

All the three species of the civets recorded from Wayanad Wildlife Sanctuary in the Western Ghats were nocturnal with varying temporal activities, while the mongooses were diurnal (Sreekumar \& Nameer 2018). In Sumatra, a study on the activity pattern of the small carnivores found that all the six species of viverrids in the study area were nocturnal with temporal variations in the activity peaks in an oil palm plantation. At the same time, the Yellow-throated Marten Martes flavigula was diurnal (Solina et al. 2018), the Nilgiri Marten of Pampadum Shola NP in the Western Ghats was also diurnal in habit (Anil et al. 2018). The nocturnal nature of the Small Indian Civets was proved in other studies from the Western Ghats, too (Pillay 2009; Chen et al. 2019; Kalle et al. 2013b). However, Selvan et al. (2019), in a study in the Villupuram district of Tamil Nadu, observed that Small Indian Civets were active during daytime hours.

The present study is expected to gather additional information on the diel activity pattern of the small carnivores of Western Ghats. 


\section{STUDY AREA AND METHODS}

\section{Study Area}

The study was conducted at Nelliyampathy Reserve Forests (NRF), in the Anamalai Hills, southern Western Ghats, India (Figure 1). The Nelliampathy reserve forest lies between $10.374-10.686{ }^{\circ} \mathrm{N}$ latitudes and 76.518$76.752{ }^{\circ} \mathrm{E}$ longitudes in the Palakkad district, Kerala, and has an extent of $206 \mathrm{~km}^{2}$. The altitude varies from $40 \mathrm{~m}$ to $1,530 \mathrm{~m}$, and the primary vegetation type is west coast tropical evergreen forest. The dominant trees are Cinnamomum malabatrum, Drypetes roxburghii, Holigarna arnottiana, Mesua ferrea, Palaquim ellipticum, Schleichera oleosa, Syzygium cumini, and Vateria indica. The average temperature ranges $21-41{ }^{\circ} \mathrm{C}$ during summer, and the temperature can be as low as $10^{\circ} \mathrm{C}$ during the winter in the upper reaches of the Nelliampathies. The mean annual rainfall is 2,500mm (Varghese 2015).

\section{Methods}

A total of 30 camera trapping stations were selected in the NRF based on indirect evidence such as scats, pugmarks, and scratches of the small carnivores. We de- ployed camera traps (Cuddeback attack model C1: digital scout cameras with passive infra-red sensors for heat and motion detection) at these locations during January 2019 at the height of $30 \mathrm{~cm}$ from the ground, and two cameras were placed at least $250 \mathrm{~m}$ from each other (Mudappa et al. 2007; Sreehari \& Nameer 2016; Nikhil \& Nameer 2017; Sanghamithra \& Nameer 2018; Sreekumar \& Nameer 2018). The cameras were set up in default settings. The time delay between the pictures during the day was set as fast as possible, and during the night, it was set with a time delay of five seconds. Garmin GPS etrex 30 was used to mark the camera trap stations. The cameras were kept open for 24 hours a day for 28 days at each location. Thus, 840 camera trap days, monitoring for 20,160 hours of trap effort, were carried out in NRF during the study period.

\section{Camera trap success rate}

The camera trap success rate is the ratio of independent photo events to the whole camera trap days and the value multiplied by 100 (Rovero \& Marshall 2009). The number of independent images of small carnivore camera trapped from NRF was used to calculate the camera trap success rate.
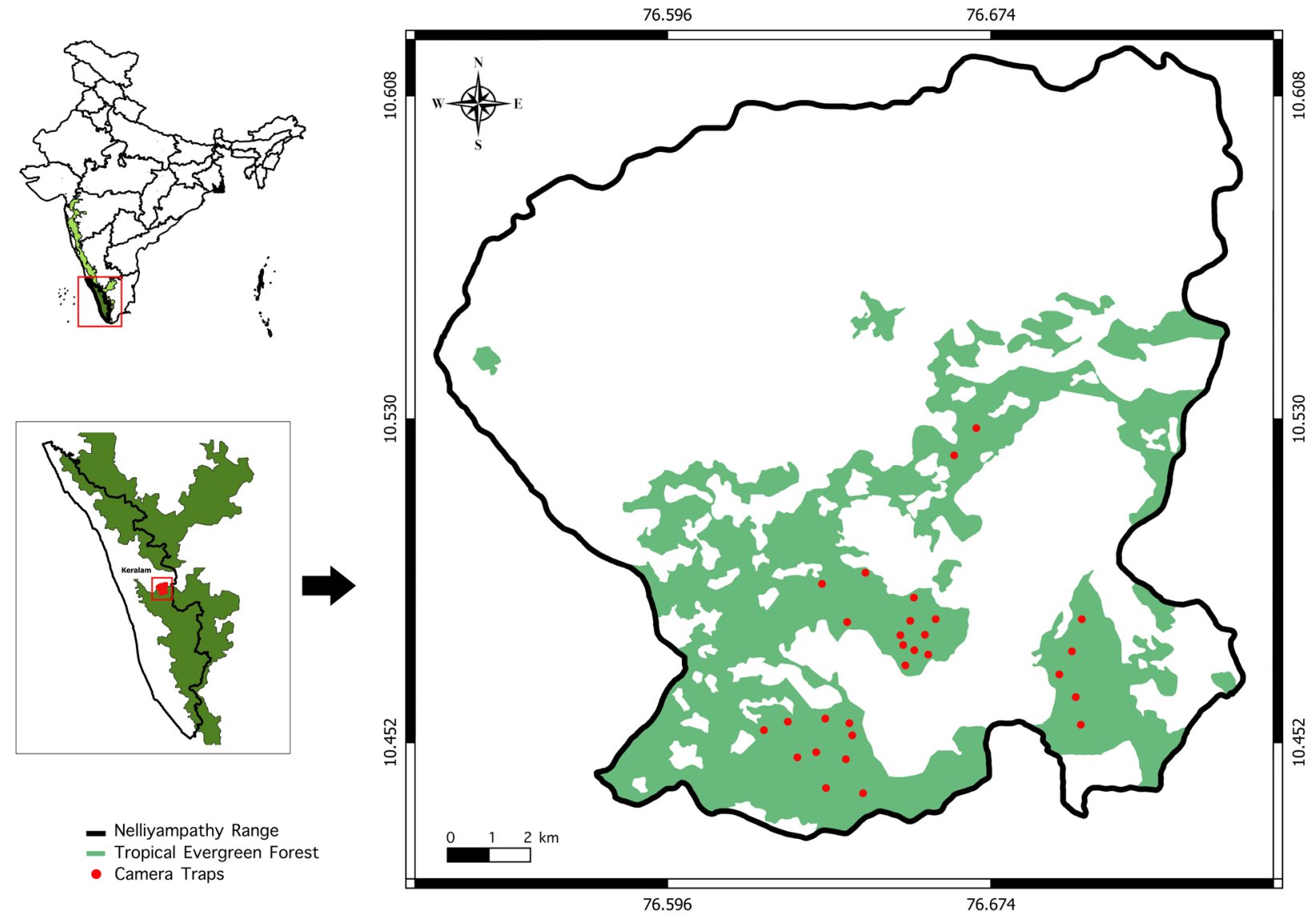

Figure 1. Camera trap locations at Nelliampathy Reserved Forest, Western Ghats, southern India. 


\section{Line transect survey for indirect evidence}

The transects were done on the existing trails, forest roads, and streams, searching for indirect evidence of small carnivores. A total of $104 \mathrm{~km}$ was walked through the various trails in search of indirect evidences of small carnivores. The scats were identified to the family level of small carnivores or the species level (Silveria et al. 2003; Sridhar et al. 2008; Mudappa et al. 2010; Perincherry et al. 2011).

\section{Analysis of diel activity}

We recorded species of small carnivores, date, time, and geocoordinates of the trap location for every camera trap image captured. To ensure the independence of the capture, we have defined successive images of the same species at the same camera trap station within a recess of $\leq 30$ minutes as a single event (Linkie \& Ridout 2011; Mukherjee et al. 2019; Selvan et al. 2019). However, if more than one individual of similar or different species were captured in a single image, each individual was considered a discrete incident (Mukherjee et al. 2019). The timings of dawn and dusk in the study area were recorded during the study period. Sunrise and sunset were at about $0645 \mathrm{~h}$ and $1815 \mathrm{~h}$ local time (GMT+5), respectively (IMD 2019). Based on dawn and dusk, the day was divided into three periods, 0745-1715 as day, 1915-0545 as night, and 0545-0745 (dawn) \& 1715-1915 (dusk) as crepuscular (Gerber et al. 2012; Selvan et al. 2019).

The diel activity of species was categorized as diurnal ( $<10 \%$ of records at night), nocturnal ( $>90 \%$ of records at night), primarily diurnal (10-29\% of records at night), mostly nocturnal (70-89\% of records at night) or cathemeral (30-69 \% of records at night) (Gomez et al. 2005; Azevedo et al. 2018; Selvan et al. 2019).

The diel activity pattern and activity overlapping were determined using a non-parametric circular Kernal density method. Soothing parameter of 0.8 (sample size <50) was used to generate coefficient of overlap $(\Delta)$ (Ridoout \& Linkie 2009). The range of coefficient of activity overlap varies from 0 (zero overlaps) to 1 (100\% overlap) (Ridoout \& Linkie 2009). R-package' OVERLAP' was used to analyze activity patterns of single species and coefficient of overlapping between two species (Meredith \& Ridout 2018). To obtain a bias-corrected percentile, we estimated the $95 \%$ confidence interval of $\Delta$ with 1,000 bootstrap (Meredith \& Ridout 2018).

\section{RESULTS AND DISCUSSION}

\section{Diversity of small carnivores at Nelliampathy Reserve Forests, Western Ghats}

We recorded six species of small carnivores from NRF representing four families. This comprises two species each of herpestids and viverrids and one species each of felids and mustelids (Table 1). A total of 677 images of 24 species of mammals were obtained during the study period. Two-hundred-and-thirty-one images were of carnivores, out of which 199 (86.15\%) were of small carnivores (Figure 2). The small carnivores recorded from NRF include Brown Palm Civet $P$. jerdoni (43.65 \%) (Image 1), Stripe-necked Mongoose $H$. vitticollis (26.39\%) (Image 2), Brown Mongoose H. fuscus (13.19\%) (Image 3), Small Indian Civet V. indica (13\%) (Image 4), Nilgiri Marten $M$. gwatkinsii (3 \%) (Image 5), and Leopard Cat Prionailurus bengalensis (1\%) (Image 6) (Figure 3).

The small carnivore camera trap success rate from the evergreen forests of NRF was 22.14 per 100 trap nights. The camera trap success rate of NRF is much higher than earlier camera trap studies from various locations in the Western Ghats. For example, the camera trap success rate of Silent Valley National Park was 10.90 per 100 camera trap nights (Sanghamithra \& Nameer 2018), Parambikulam Tiger Reserve was 4.40 (Sreehari \& Nameer 2016),

Table 1. Small carnivores of Nelliampathy Reserve Forest, Western Ghats, southern India.

\begin{tabular}{|l|l|l|c|c|c|}
\hline Common name & Scientific name & Family & $\begin{array}{c}\text { IUCN } \\
\text { Red List } \\
\text { status }\end{array}$ & CT & IE \\
\hline Brown Palm Civet & Paradoxurus jerdoni & Viverridae & LC & $*$ & $*$ \\
\hline Small Indian Civet & Viverricula indica & Viverridae & LC & $*$ & \\
\hline Brown Mongoose & Herpestes fuscus & Herpestidae & LC & $*$ & \\
\hline Stripe-necked Mongoose & Herpestes vitticollis & Herpestidae & LC & $*$ & \\
\hline Nilgiri Marten & Martes gwatkinsii & Mustelidae & VU & $*$ & \\
\hline Asian Small-clawed Otter & Aonyx cinereus & Mustelidae & VU & & $*$ \\
\hline Leopard Cat & Prionailurus bengalensis & Felidae & LC & $*$ & $*$ \\
\hline
\end{tabular}

CT-Camera trap | IE-Indirect evidence. 


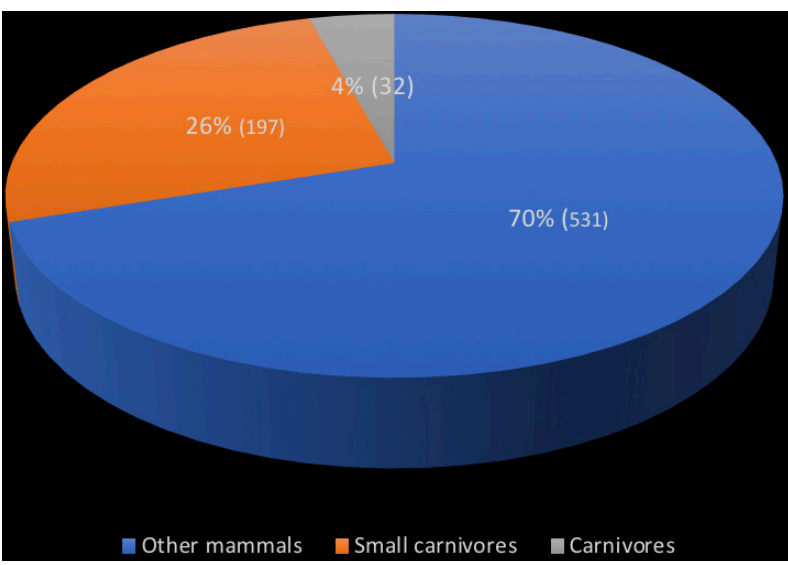

Figure 2. Relative abundance of mammals captured in the camera traps in Nelliyampathy Reserve Forest, Western Ghats, southern India.

and Eravikulam National Park was 2.10 (Nikhil \& Nameer 2017). However, a higher camera trap success rate 41.10 per 100 trap nights was recorded from Kalakkad Mundanthurai Tiger Reserve (Mudappa et al. 2007).

\section{Diel activity of small carnivores at Nelliampathy Reserve Forests, Western Ghats}

The maximum diel activity overlap was detected between Brown Palm Civet and Small Indian Civet with $\Delta$ of 0.81 (0.66-0.92) (Fig. 4a), followed by Brown Mongoose and Small Indian Civet $(\Delta=0.76,0.58-0.91)$ (Figure $4 \mathrm{~b})$, and then Brown Mongoose and Brown Palm Civet ( $\Delta=$ $0.70,0.53-0.83$ ) (Figure 4c). Whereas, the minimal die activity overlap was observed between Stripe-necked Mongoose and Small Indian Civet $(\Delta=0.08,0.01-0.18)$ (Figure 4f), Stripe-necked Mongoose and Brown Palm Civet $(\Delta=0.13,0.06-0.21$ ) (Figure $4 \mathrm{e})$, and between Stripe-necked Mongoose and Brown Mongoose $(\Delta=0.20$ 0.08-0.33) (Figure 4d).

The most significant diel activity overlap was between Brown Palm Civet and Small Indian Civet. Even though they are similar in size and activity, the competition for resources may be minimized by the dissimilarity in their dietary preferences. Brown Palm Civet is primarily frugivorous (Rajamani et al. 2002; Mudappa et al. 2010), whereas Small Indian Civet is a generalist and omnivorous (Mudappa et al. 2007).

Brown Palm Civet, Small Indian Civet, and Brown Mongoose displayed nocturnal activity patterns, and they have the most significant overlap in the diel activity. However, they all showed varying activity peaks, probably to reduce the competition. Activity peaks of Brown Palm Civet were just before dawn (0400-0600 h) and just after dusk (1800-2000 h), whereas Small Indian Civet had activity peaks were during midnight hours $(0000-0100 \mathrm{~h})$

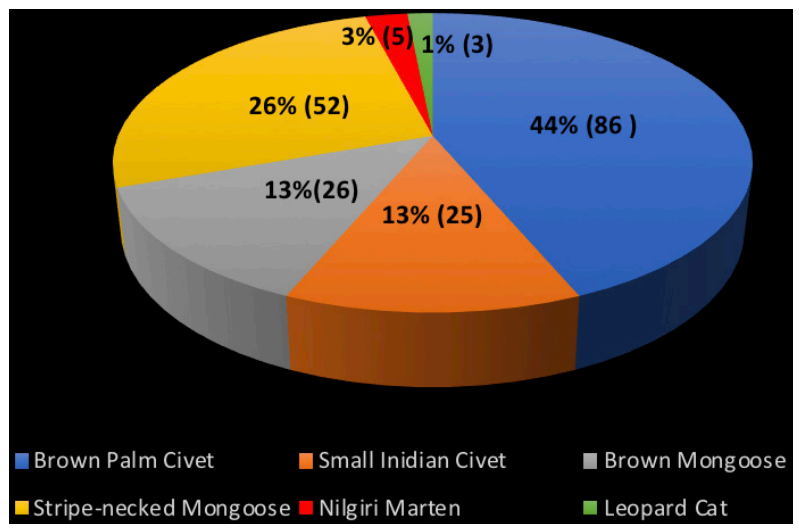

Figure 3. Relative abundance of small carnivores captured in the camera traps in Nelliyampathy Reserve Forest, Western Ghats, southern India.

and soon after sunset (1900-2030 h). Brown Mongoose showed peak activity during the midnight hours from 2300 to $0100 \mathrm{~h}$. Similar activity patterns and overlap were observed among the Small Indian Civet and Brown Palm Civet in Wayanad Wildlife Sanctuary (Sreekumar \& Nameer 2018). The diel overlap between Common Palm Civet and Small Indian Civet both showed nocturnal activity but varying activity peaks (Su \& Sale 2007).

The activity pattern not only depends on factors like limited resources and competition but also on seasonal changes (Ikeda et al. 2016), changes in diurnal temperatures (Fuller et al. 2016) prey-predator interactions (Harmse et al. 2011; Linkie \& Ridout 2011) and human interventions and human activity (Cruz et al. 2018). It needs to be further investigated to understand how the sympatric species with overlapping diel activity perform the resource partitioning.

\section{CONCLUSION}

Depending on the time of the activity of a species, the small carnivores are generally grouped into two, nocturnal and diurnal. Species within the same temporal group have a more significant overlap in their activity. Maximum overlap was observed between two nocturnal small carnivores, Brown Palm Civet and Small Indian Civet. At the same time, the lowest overlap in activity was observed between Stripe-necked Mongoose and Small Indian Civet.

Diel activity patterns are a vital feature of animal behaviour with important implications for a wide range of ecological and physiological processes. Diel activity patterns are an adaptation to environmental variability throughout the day. They reflect a complex compromise 


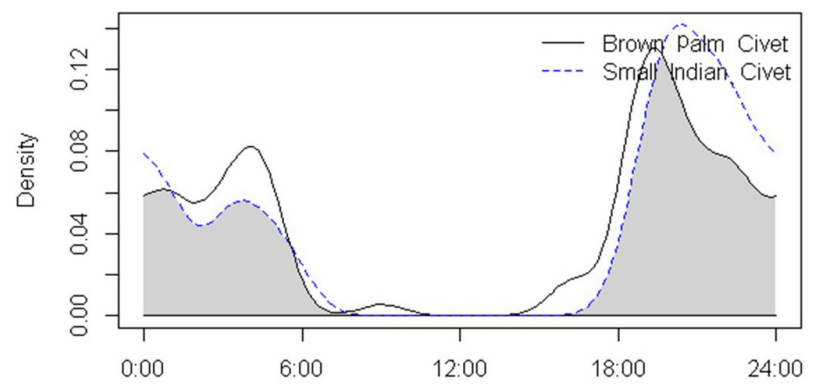

Fig. 4a

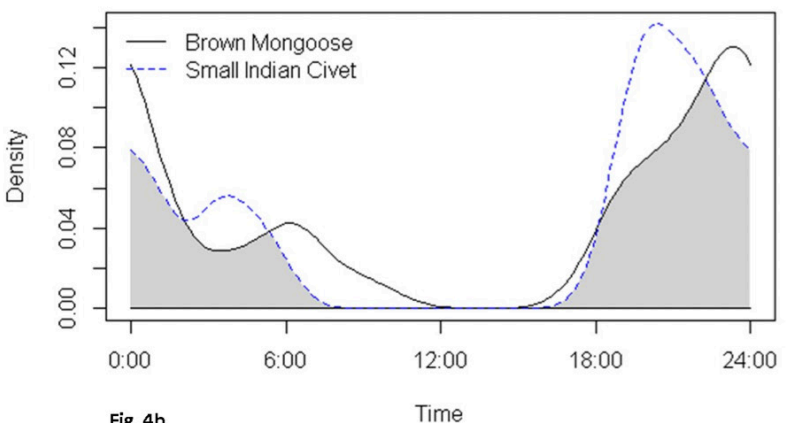

Fig. $4 \mathrm{~b}$

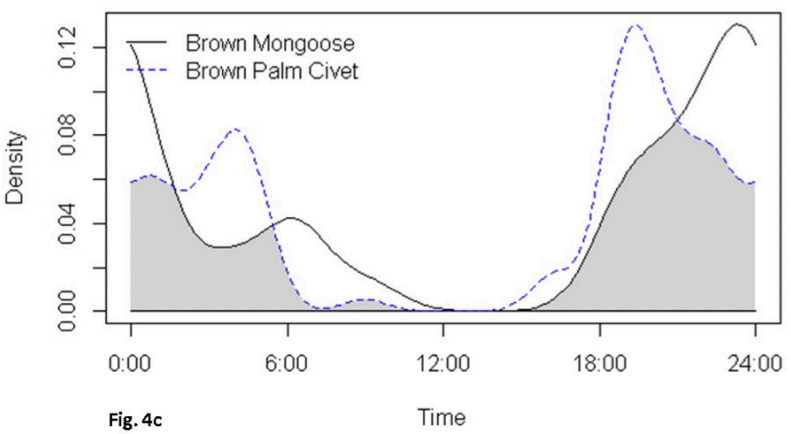

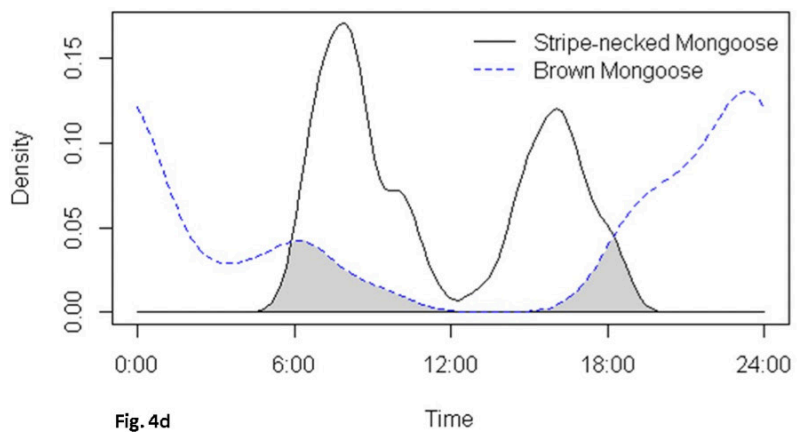
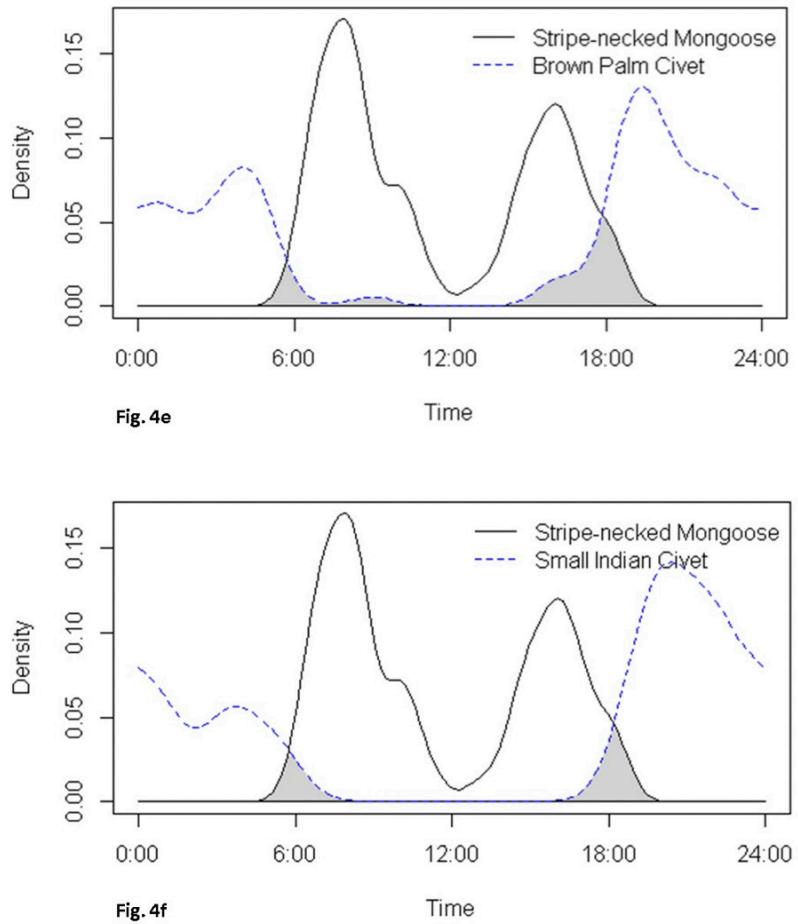

Figure 4. The activity pattern of small carnivores of Nelliyampathy Reserve Forest, Western Ghats, southern India: a-Brown Palm Civet \& Small Indian Civet | b-Brown Mongoose \& Small Indian Civet | c-Brown Mongoose \& Brown Palm Civet | d-Stripe-necked Mongoose \& Brown Mongoose | e-Stripe-necked Mongoose \& Brown Palm Civet | f-Stripe-necked Mongoose \& Small Indian Civet.

between foraging, resting, predator avoidance, competition, social activities and environmental constraints determining fitness. Thus, the diel activity studies may enable us to perform more robust comparisons of activity patterns and levels across sites and species to better understand ecological and human drivers of these processes and thus have management and conservation significance.

\section{REFERENCES}

Anil, G., N. Kishor, G. Naseef, N. Ommer \& P.O. Nameer (2018). Observations on the Nilgiri Marten Martes gwatkinsii (Mammalia: Carnivora: Mustelidae) from Pampadum Shola National Park, southern Western Ghats, India. Journal of Threatened Taxa 10(1): 11226-11230. http://doi.org/10.11609/jott.3446.10.1.11226- 11230
Anoop, K.R. \& S.A. Hussain (2004). Factors affecting habitat selection by Smooth-coated Otters Lutra perspicillata in Kerala, India. Journal of Zoological Society 263(4): 417-423.

Anoop, K.R. \& S.A. Hussain (2005). Food and feeding habits of Smoothcoated Otters (Lutra perspicillata) and their significance to the fish population of Kerala, India. Journal of Zoological Society 266(1): 15-23.

Azevedo, F.C., F.G. Lemos, M.C. Freitas-junior, D.G. Rocha \& F.C.C. Azevedo (2018). Puma activity patterns and temporal overlap with prey in a human-modified landscape in southeastern Brazil. Journal of Zoology (London) 305: 246-255. https://doi.org/10.1111/jzo.12558

Bhosale, H.S., G.A. Punjabi \& R. Bardapurkar (2013). Photographic documentation of Brown Palm Civet Paradoxurus jerdoni in Maharashtra, India, North of its known range. Small Carnivore Conservation 49: 37-39.

Chen, M.T., M.E. Tewes, K.J. Pei \& L.I. Grassman Jr. (2009). Activity patterns and habitat use of sympatric small carnivores in southern Taiwan. Mammalia 73: 20-26

Cruz, P., M.E. lezzi, C. De Angelo, D. Varela, M.S. Di Bitetti \& A. Paviolo (2018). Effects of human impacts on habitat use, activity patterns 


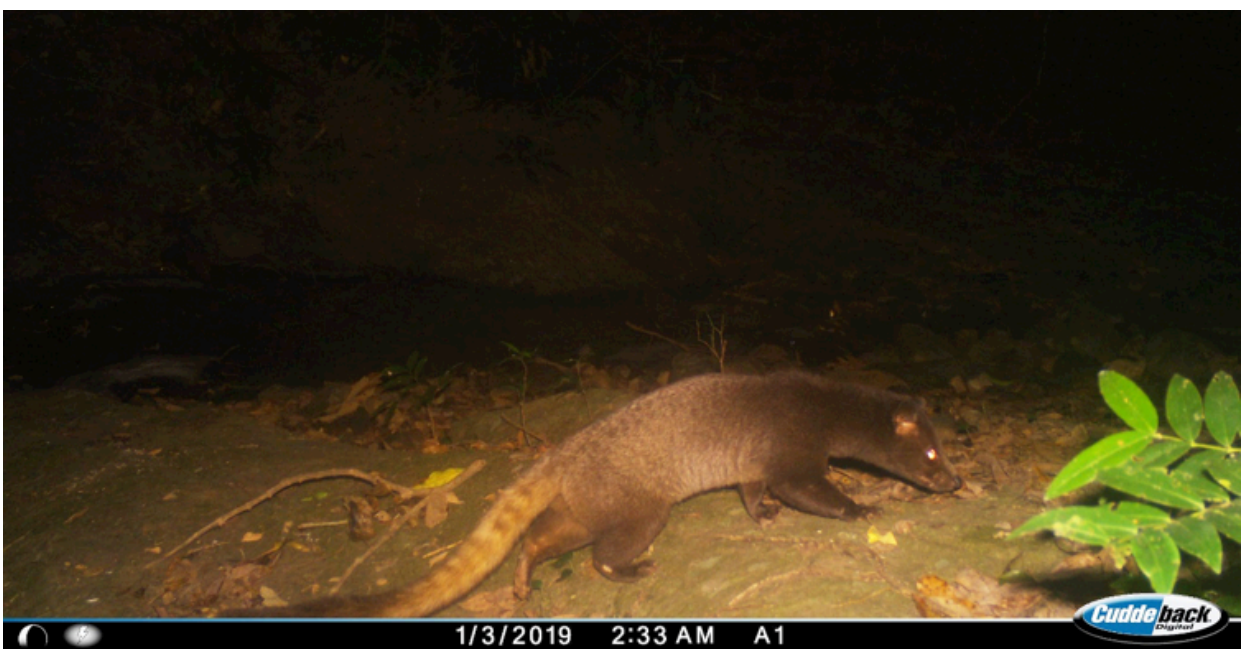

Image 1. Brown Palm Civet Paradoxurus jerdoni in Nelliyampathy Reserve Forest, Western Ghats, southern India.

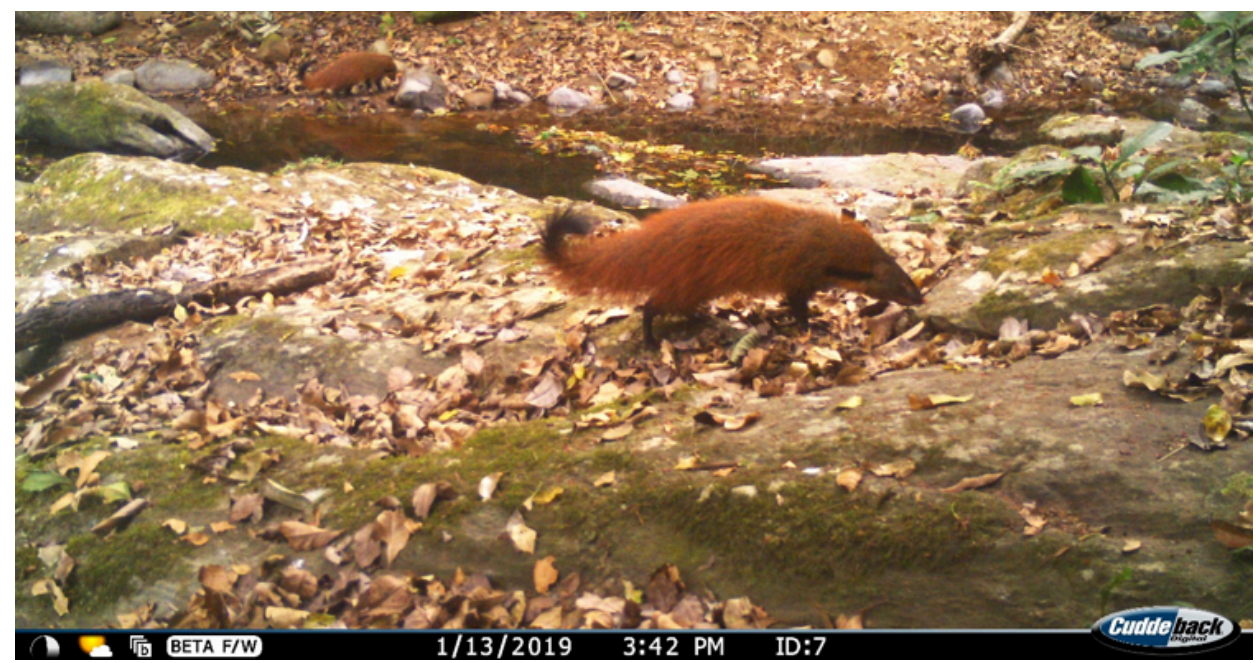

Image 2. Stripe-necked Mongoose Herpestes vitticollis in Nelliyampathy Reserve Forest, Western Ghats, southern India.

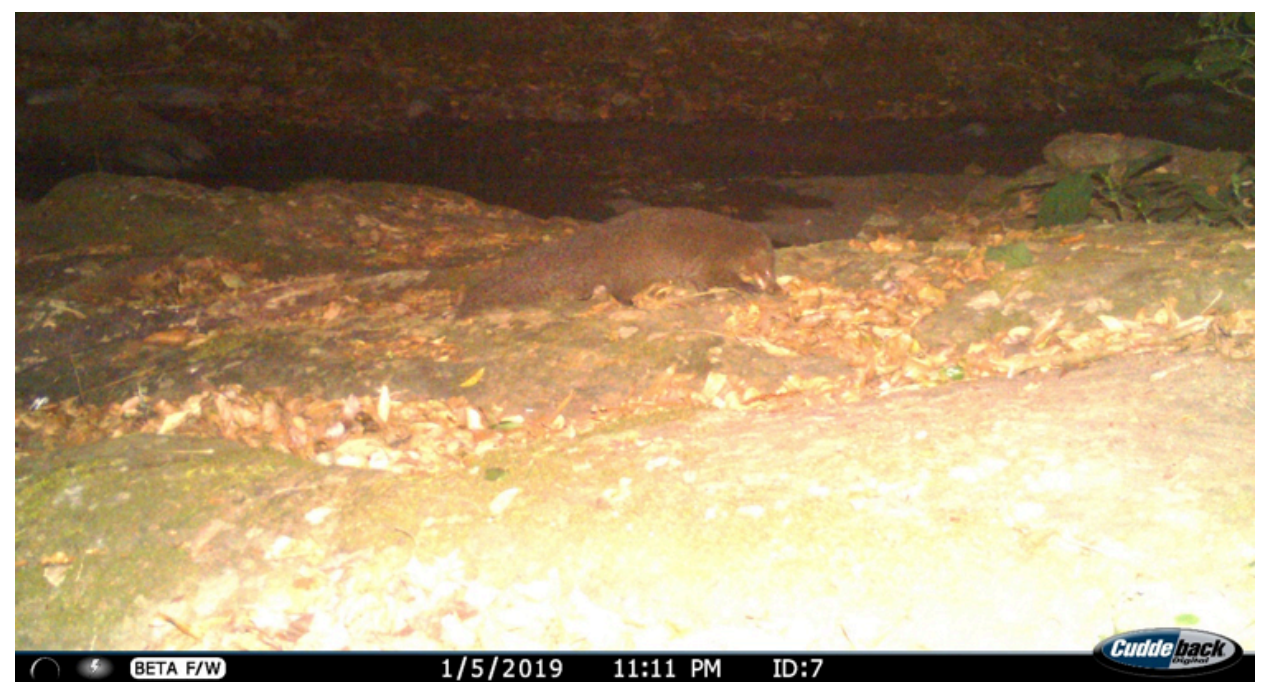

Image 3. Brown Mongoose Herpestes fuscus in Nelliyampathy Reserve Forest, Western Ghats, southern India. 


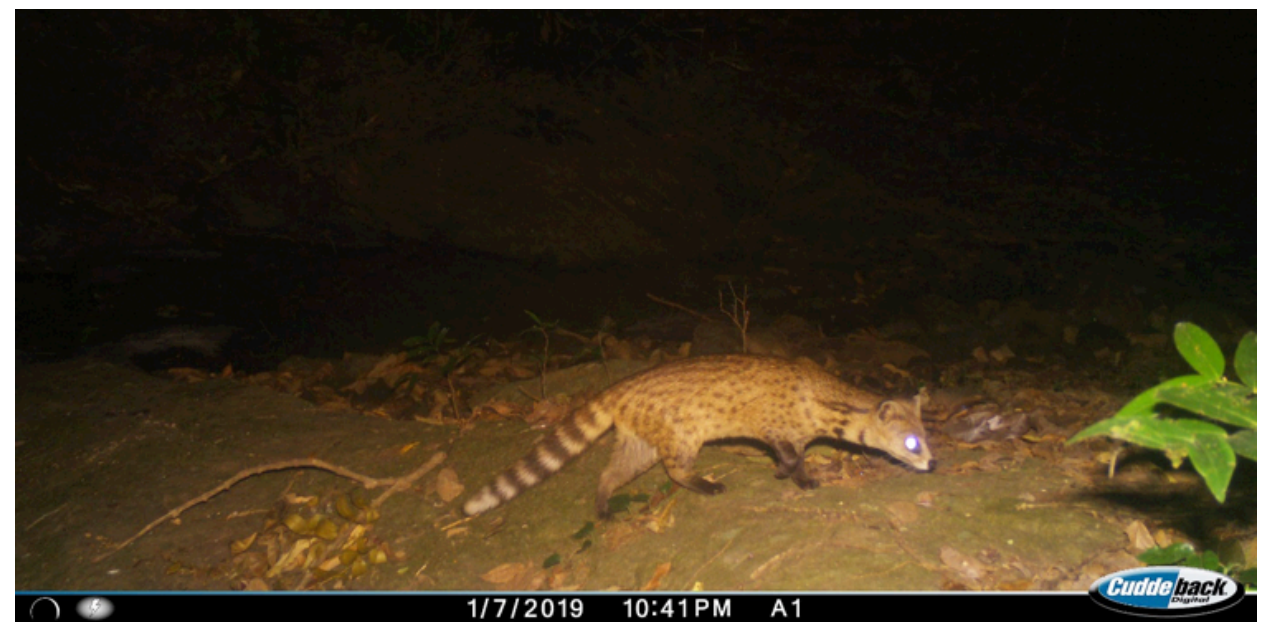

Image 4. Small Indian Civet Viverricula indica in Nelliyampathy Reserve Forest, Western Ghats, southern India.

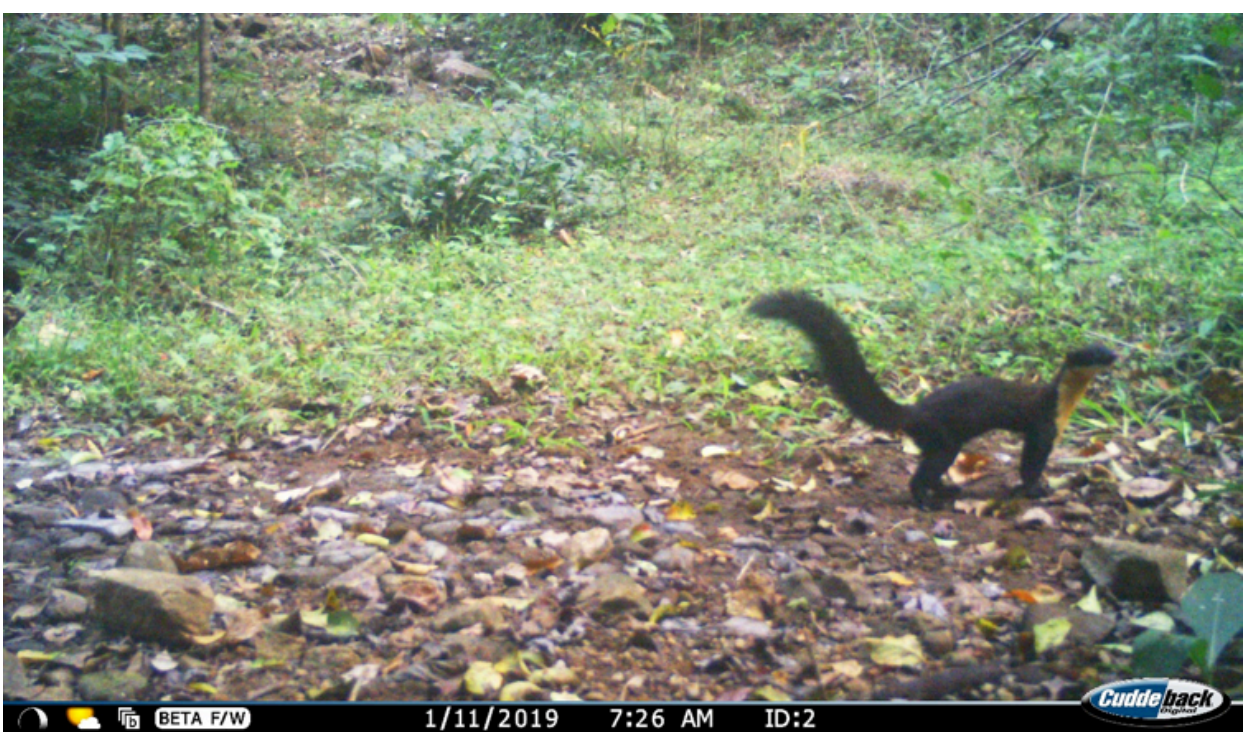

Image 5. Nilgiri Marten Martes gwatkinsii in Nelliyampathy Reserve Forest, Western Ghats, southern India.

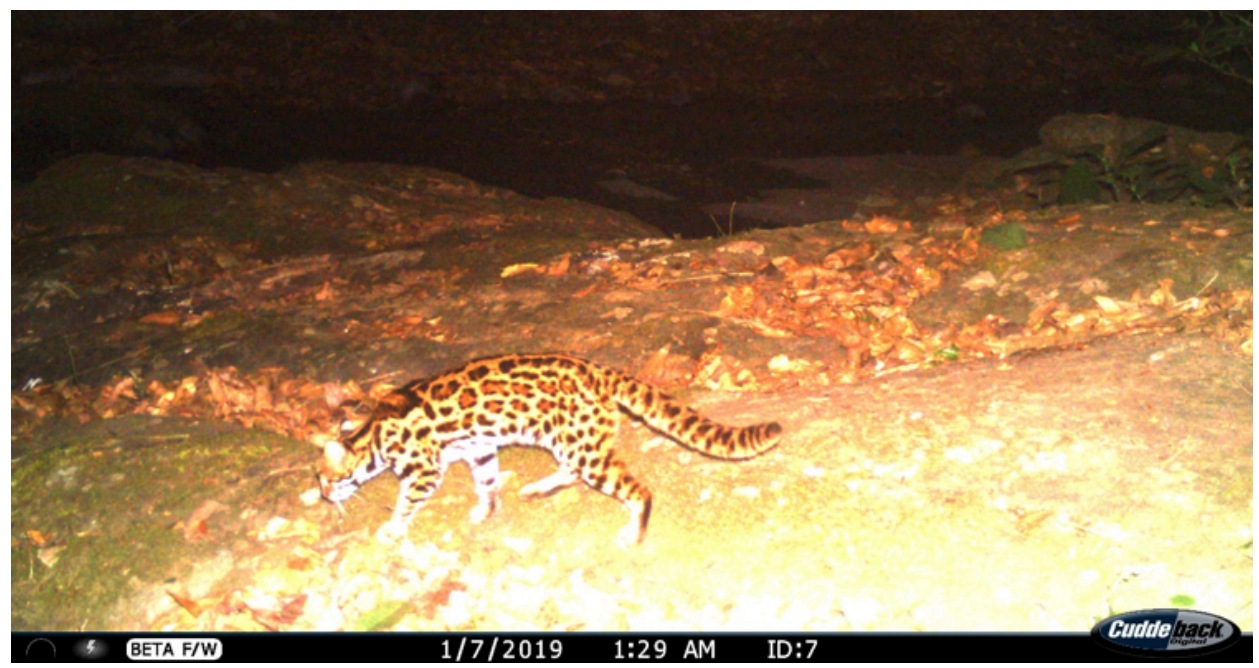

Image 6. Leopard Cat Prionailurus bengalensis in Nelliyampathy Reserve Forest, Western Ghats, southern India. 
and ecological relationships among medium and small felids of the Atlantic Forest. PLoS ONE 13(8): e0200806. https://doi.org/10.1371/ journal.pone.0200806

Fuller, A., D. Mitchell, S.K. Maloney \& R.S. Hetem (2016). Towards a mechanistic understanding of the responses of large terrestrial mammals to heat and aridity associated with climate change. Climate Change Responses 3(1): 1-19.

Gerber, B., S.M. Karpanty \& J. Randrianantenaina (2012). Activity pat terns of carnivores in the rain forests: implications for species coexistence. Journal of Mammalogy 93: 667-676.

Gomez, H., R.B. Wallace, G. Ayala \& R. Tejada (2005). Dry season activity periods of some Amazonian mammals. Studies on Neotropical Fauna and Environment 40: 91-95. https://doi. org/10.1080/01650520500129638

Harmsen B.J., R.J. Foster, S.C. Silver, E.T.O. Linde \& C.P. Doncaster (2011). Jaguar and Puma activity patterns in relation to their main prey. Mammalian Biology 76: 320-324. https://doi:10.1016/j. mambio.2010.08.007

Ikeda, T., K. Uchida, Y. Matsuura, H. Takahashi, T. Yoshida, K. Kaji \& I. Koizumi (2016). Seasonal and diel activity patterns of eight sympatric mammals in Northern Japan revealed by an intensive camera-trap survey. PLoS One 11(10): e0163602. https://doi.org/10.1371/journal. pone.0163602

IMD (Indian Meteorological Department) (2019). IMD; an online data base of Weather data of Palakkad District [web application]. Indian Meteorological Department, Ministry of Earth Sciences, Government of India, New Delhi, https://mausam.imd.gov.in/index.php

Kalle, R., T. Ramesh, Q. Qureshi \& K. Sankar (2013a). Predicting the distribution pattern of small carnivores in response to environmenta factors in the Western Ghats. Plos One 8(11): e79295. https://doi. org/10.1371/journal.pone.0079295

Kalle, R., T. Ramesh, K. Sankar \& Q. Qureshi (2013b). Observations of sympatric small carnivores in Mudumalai Tiger Reserve, Western Ghats, India. Small Carnivore Conservation 44: 53-59.

Kumara, H.N. \& M. Singh (2006). Small carnivores of Karnataka: distribution and sight records. Journal of the Bombay Natural History Society 104(2): 155-162.

Kumara, H.N., O. Thorat, K. Santhosh, R. Sasi \& H.P. Ashwin (2014) Small carnivores of Biligiri Rangaswamy Temple Tiger Reserve, Karnataka, India. Journal of Threatened Taxa 6(12): 6534-6543. https://doi. org/10.11609/JoTT.o3766.6534-43

Linkie, M. \& M.S. Ridout (2011). Assessing tiger-prey interactions in Sumatran rainforests. Journal of Zoology (London) 284: 224-229. https://doi.org/10.1111/j.1469-7998.2011.00801.x

Meredith, M. \& M. Ridout (2018). Package 'overlap': estimates of coefficient of overlapping for animal activity patterns. R Package Version 0.3.2. Accessed 21 April 2019. Available online at https://cran.r-project.org/web/packages/overlap/overlap.pdf

Mudappa, D., A. Kumar \& R. Chellam (2010). Diet and fruit choice of the brown palm civet Paradoxurus jerdoni, a viverrid endemic to the Western Ghats rainforest, India. Tropical Conservation Science 3(3): 282-300.

Mudappa, D., B.R. Noon, A. Kumar \& R. Chellam (2007). Responses of small carnivores to rain forest fragmentation in the southern Western Ghats, India. Small Carnivore Conservation 36: 18-26.

Mukherjee, S., P. Singh, A.P. Silva, C. Ri, K. Kakati, B. Borah, T. Tapi, S. Kadur, P. Choudhary, S. Srikant, S. Nadig, R. Navya, M. Björklund \& U. Ramakrishnan (2019). Activity patterns of the small and medium felid (Mammalia: Carnivora: Felidae) guild in northeastern India. Journal of Threatened Taxa 11(4): 13432-13447. https://doi.org/10.11609/ jott.4662.11.4.13432-13447

Nameer, P.O. (2015). A checklist of mammals of Kerala, India. Journal of Threatened Taxa 7(13): 7971-7982. https://doi.org/10.11609/ jott.2000.7.13.7971-7982

Nameer, P.O. (2020). JoTT Checklist of the mammals of Kerala (v1.0), 01 January 2020. https://threatenedtaxa.org/index.php/JoTT/checklists/ mammals/westernghats

Nikhil, S. \& P.O. Nameer (2017). Small carnivores of the montane for ests of Eravikulam National Park in the Western Ghats, India. Journal of Threatened Taxa 9(11): 10880-10885. http://doi.org/10.11609/ jott.2211.9.11.10880-10885

Perinchery, A., D. Jathanna \& A. Kumar (2011). Factors determining occupancy and habitat use by Asian small-clawed otters in the Western Ghats, India. Journal of Mammalogy 92(4): 796-802.

Pillay, R. (2009). Observations of small carnivores in the southern Western Ghats, India. Small Carnivore Conservation 40: 36-40.

Punjabi, G.A., A.S. Borker, F. Mhetar, D. Joshi, R. Kulkarni, S.K. Alave \& M.K. Rao (2014). Recent records of Stripe-necked Mongoose Herpestes vitticollis and Asian Small-clawed Otter Aonyx cinereus from the north Western Ghats, India. Small Carnivore Conservation 51: 51-55.

Rajamani, N., D. Mudappa \& H.V. Rompaey (2002). Distribution and status of the Brown Palm Civet in the Western Ghats, South India. Small Carnivore Conservation 27(2): 6-11.

Raman, S., T.T Shameer, R. Sanil, P. Usha \& S. Kumar (2020). Protrusive influence of climate change on the ecological niche of endemic brown mongoose (Herpestes fuscus fuscus): a MaxEnt approach from the Western Ghats, India. Modelling Earth Systems and Environment 6(3): 1795-1806. https://doi.org/10.1007/s40808-020-00790-1

Ridout, M.S. \& M. Linkie (2009). Estimating overlap of daily activity patterns from camera-trap data. Journal of Agricultural, Biological, and Environmental Statistics 14: 322-337.

Rovero, F. \& A.R. Marshall (2009). Camera trapping photographic rate as an index of density in forest ungulates. Journal of applied Ecology 46(5): 1011-1017.

Sanghamithra, D. \& P.O. Nameer (2018). Small carnivores of Silent Valley National Park, Kerala, India. Journal of Threatened Taxa 10(8): 1209112097. https://doi.org/10.11609/jott.2992.10.8.12091-12097

Sayyed, A., S.S. Talmale \& A. Mahabal (2019). Records of Brown Palm Civet Paradoxurus jerdoni in Satara district, Maharashtra: extension of known range in Western Ghats, India. Zoo's Print 34(9): 8-11.

Selvan, K.M., B.M. Krishnakumar, P. Ramasamy \& T. Thinesh (2019). Diel activity pattern of meso-carnivores in the suburban tropical dry evergreen forest of the Coromandel Coast, India. Journal of Threatened Taxa 11(8): 13960-13966. https://doi.org/10.11609/ jott.4850.11.8.13960-13966

Silveira, L., A.T.A. Ja'como \& J.A.F. Diniz-Filho (2003). Camera trap, line transect census and track surveys: a comparative evaluation. Biological Conservation 114: 351-355. https://doi.org/10.1016/S00063207(03)00063-6

Solina, I.D., W. Novarino, Rizaldi \& A.J. Giordano (2018). Activty pattern and habitat profile of small carnivores in and oil palm landscape. Journal of Indonesian Natural History 6(1): 18-27.

Sreehari, R. \& P.O. Nameer (2016). Small carnivores of Parambikulam Tiger Reserve, southern Western Ghats, India. Journal of Threatened Taxa 8(11): 9306-9315. https://doi.org/10.11609/ jott.2311.8.11.9306-9315

Sreekumar, E.R. \& P.O. Nameer (2018). Small carnivores of Wayanad Wildlife Sanctuary, the southern Western Ghats, India. Journal of Threatened Taxa 10(1): 11218-11225. https://doi.org/10.11609/ jott.3651.10.1.11218-11225

Sridhar, H., T.R.S. Raman \& D. Mudappa (2008). Mammal persistence and abundance in tropical rainforest remnants in the southern Western Ghats, India. Current Science 94: 748-757.

Su, S. \& J. Sale (2007). Niche differentiation between common Palm Civet Paradoxurus hermaphrodites and Small Indian Civet Viverricula indica in regenerating degraded forest, Myanmar. Small Carnivore Conservation 36: 30-34.

Suthar, S., A. Menon \& S. Gubbi (2020). An extension of the known range of Brown Mongoose Urva fuscus in southern India. Small Carnivore Conservation 58: e58007.

Varghese S. (2015). Working Plan of Nenmara Forest Division 20152025. Kerala Forest Department, Thiruvananthapuram, 469 pp.

Wilson, D.E. \& R.A. Mittermeier (2009). Handbook of the Mammals of the World, Vol. 1. Lynx Edicions in association with Conservation International and IUCN, 728pp. 

Dr. Albert G. Orr, Griffith University, Nathan, Australia

Dr. Sameer Padhye, Katholieke Universiteit Leuven, Belgium

Dr. Nancy van der Poorten, Toronto, Canada

Dr. Kareen Schnabel, NIWA, Wellington, New Zealand

Dr. R.M. Sharma, (Retd.) Scientist, Zoological Survey of India, Pune, India

Dr. Manju Siliwal, WILD, Coimbatore, Tamil Nadu, India

Dr. G.P. Sinha, Botanical Survey of India, Allahabad, India

Dr. K.A. Subramanian, Zoological Survey of India, New Alipore, Kolkata, India

Dr. P.M. Sureshan, Zoological Survey of India, Kozhikode, Kerala, India

Dr. R. Varatharajan, Manipur University, Imphal, Manipur, India

Dr. Eduard Vives, Museu de Ciències Naturals de Barcelona, Terrassa, Spain

Dr. James Young, Hong Kong Lepidopterists' Society, Hong Kong

Dr. R. Sundararaj, Institute of Wood Science \& Technology, Bengaluru, India

Dr. M. Nithyanandan, Environmental Department, La Ala Al Kuwait Real Estate. Co. K.S.C., Kuwait

Dr. Himender Bharti, Punjabi University, Punjab, India

Mr. Purnendu Roy, London, UK

Dr. Saito Motoki, The Butterfly Society of Japan, Tokyo, Japan

Dr. Sanjay Sondhi, TITLI TRUST, Kalpavriksh, Dehradun, India

Dr. Nguyen Thi Phuong Lien, Vietnam Academy of Science and Technology, Hanoi, Vietnam

Dr. Nitin Kulkarni, Tropical Research Institute, Jabalpur, India

Dr. Robin Wen Jiang Ngiam, National Parks Board, Singapore

Dr. Lional Monod, Natural History Museum of Geneva, Genève, Switzerland.

Dr. Asheesh Shivam, Nehru Gram Bharti University, Allahabad, India

Dr. Rosana Moreira da Rocha, Universidade Federal do Paraná, Curitiba, Brasil

Dr. Kurt R. Arnold, North Dakota State University, Saxony, Germany

Dr. James M. Carpenter, American Museum of Natural History, New York, USA

Dr. David M. Claborn, Missouri State University, Springfield, USA

Dr. Kareen Schnabel, Marine Biologist, Wellington, New Zealand

Dr. Amazonas Chagas Júnior, Universidade Federal de Mato Grosso, Cuiabá, Brasil

Mr. Monsoon Jyoti Gogoi, Assam University, Silchar, Assam, India

Dr. Heo Chong Chin, Universiti Teknologi MARA (UiTM), Selangor, Malaysia

Dr. R.J. Shiel, University of Adelaide, SA 5005, Australia

Dr. Siddharth Kulkarni, The George Washington University, Washington, USA

Dr. Priyadarsanan Dharma Rajan, ATREE, Bengaluru, India

Dr. Phil Alderslade, CSIRO Marine And Atmospheric Research, Hobart, Australia

Dr. John E.N. Veron, Coral Reef Research, Townsville, Australia

Dr. Daniel Whitmore, State Museum of Natural History Stuttgart, Rosenstein, Germany.

Dr. Yu-Feng Hsu, National Taiwan Normal University, Taipei City, Taiwan

Dr. Keith V. Wolfe, Antioch, California, USA

Dr. Siddharth Kulkarni, The Hormiga Lab, The George Washington University, Washington,

D.C., USA

Dr. Tomas Ditrich, Faculty of Education, University of South Bohemia in Ceske

Budejovice, Czech Republic

Dr. Mihaly Foldvari, Natural History Museum, University of Oslo, Norway

Dr. V.P. Uniyal, Wildlife Institute of India, Dehradun, Uttarakhand 248001, India

Dr. John T.D. Caleb, Zoological Survey of India, Kolkata, West Bengal, India

Dr. Priyadarsanan Dharma Rajan, Ashoka Trust for Research in Ecology and the Environment (ATREE), Royal Enclave, Bangalore, Karnataka, India

\section{Fishes}

Dr. Neelesh Dahanukar, IISER, Pune, Maharashtra, India

Dr. Topiltzin Contreras MacBeath, Universidad Autónoma del estado de Morelos, México

Dr. Heok Hee Ng, National University of Singapore, Science Drive, Singapore

Dr. Rajeev Raghavan, St. Albert's College, Kochi, Kerala, India

Dr. Robert D. Sluka, Chiltern Gateway Project, A Rocha UK, Southall, Middlesex, UK

Dr. E. Vivekanandan, Central Marine Fisheries Research Institute, Chennai, India

Dr. Davor Zanella, University of Zagreb, Zagreb, Croatia

Dr. A. Biju Kumar, University of Kerala, Thiruvananthapuram, Kerala, India

Dr. Akhilesh K.V., ICAR-Central Marine Fisheries Research Institute, Mumbai Research

Centre, Mumbai, Maharashtra, India

Dr. J.A. Johnson, Wildlife Institute of India, Dehradun, Uttarakhand, India

\section{Amphibians}

Dr. Sushil K. Dutta, Indian Institute of Science, Bengaluru, Karnataka, India

Dr. Annemarie Ohler, Muséum national d'Histoire naturelle, Paris, France

\section{Reptiles}

Dr. Gernot Vogel, Heidelberg, Germany

Dr. Raju Vyas, Vadodara, Gujarat, India

Dr. Pritpal S. Soorae, Environment Agency, Abu Dubai, UAE.

Prof. Dr. Wayne J. Fuller, Near East University, Mersin, Turkey

Prof. Chandrashekher U. Rivonker, Goa University, Taleigao Plateau, Goa. India

Dr. S.R. Ganesh, Chennai Snake Park, Chennai, Tamil Nadu, India

Dr. Himansu Sekhar Das, Terrestrial \& Marine Biodiversity, Abu Dhabi, UAE
Birds

Dr. Hem Sagar Baral, Charles Sturt University, NSW Australia

Dr. Chris Bowden, Royal Society for the Protection of Birds, Sandy, UK

Dr. Priya Davidar, Pondicherry University, Kalapet, Puducherry, India

Dr. J.W. Duckworth, IUCN SSC, Bath, UK

Dr. Rajah Jayapal, SACON, Coimbatore, Tamil Nadu, India

Dr. Rajiv S. Kalsi, M.L.N. College, Yamuna Nagar, Haryana, India

Dr. V. Santharam, Rishi Valley Education Centre, Chittoor Dt., Andhra Pradesh, India

Dr. S. Balachandran, Bombay Natural History Society, Mumbai, India

Mr. J. Praveen, Bengaluru, India

Dr. C. Srinivasulu, Osmania University, Hyderabad, India

Dr. K.S. Gopi Sundar, International Crane Foundation, Baraboo, USA

Dr. Gombobaatar Sundev, Professor of Ornithology, Ulaanbaatar, Mongolia

Prof. Reuven Yosef, International Birding \& Research Centre, Eilat, Israel

Dr. Taej Mundkur, Wetlands International, Wageningen, The Netherlands

Dr. Carol Inskipp, Bishop Auckland Co., Durham, UK

Dr. Tim Inskipp, Bishop Auckland Co, Durham, UK

Dr. V. Gokula, National College, Tiruchirappalli, Tamil Nadu, India

Dr. Arkady Lelej, Russian Academy of Sciences, Vladivostok, Russia

Dr. Simon Dowell, Science Director, Chester Zoo, UK

Dr. Mário Gabriel Santiago dos Santos, Universidade de Trás-os-Montes e Alto Douro,

Quinta de Prados, Vila Real, Portugal

Dr. Grant Connette, Smithsonian Institution, Royal, VA, USA

Dr. M. Zafar-ul Islam, Prince Saud Al Faisal Wildlife Research Center, Taif, Saudi Arabia

Mammals

Dr. Giovanni Amori, CNR - Institute of Ecosystem Studies, Rome, Italy

Dr. Anwaruddin Chowdhury, Guwahati, India

Dr. David Mallon, Zoological Society of London, UK

Dr. Shomita Mukherjee, SACON, Coimbatore, Tamil Nadu, India

Dr. Angie Appel, Wild Cat Network, Germany

Dr. P.O. Nameer, Kerala Agricultural University, Thrissur, Kerala, India

Dr. Ian Redmond, UNEP Convention on Migratory Species, Lansdown, UK

Dr. Heidi S. Riddle, Riddle's Elephant and Wildlife Sanctuary, Arkansas, USA

Dr. Karin Schwartz, George Mason University, Fairfax, Virginia.

Dr. Lala A.K. Singh, Bhubaneswar, Orissa, India

Dr. Mewa Singh, Mysore University, Mysore, India

Dr. Paul Racey, University of Exeter, Devon, UK

Dr. Honnavalli N. Kumara, SACON, Anaikatty P.O., Coimbatore, Tamil Nadu, India

Dr. Nishith Dharaiya, HNG University, Patan, Gujarat, India

Dr. Spartaco Gippoliti, Socio Onorario Società Italiana per la Storia della Fauna "Giuseppe

Altobello", Rome, Italy

Dr. Justus Joshua, Green Future Foundation, Tiruchirapalli, Tamil Nadu, India

Dr. H. Raghuram, The American College, Madurai, Tamil Nadu, India

Dr. Paul Bates, Harison Institute, Kent, UK

Dr. Jim Sanderson, Small Wild Cat Conservation Foundation, Hartford, USA

Dr. Dan Challender, University of Kent, Canterbury, UK

Dr. David Mallon, Manchester Metropolitan University, Derbyshire, UK

Dr. Brian L. Cypher, California State University-Stanislaus, Bakersfield, CA

Dr. S.S. Talmale, Zoological Survey of India, Pune, Maharashtra, India

Prof. Karan Bahadur Shah, Budhanilakantha Municipality, Kathmandu, Nepal

Dr. Susan Cheyne, Borneo Nature Foundation International, Palangkaraja, Indonesia

Dr. Hemanta Kafley, Wildlife Sciences, Tarleton State University, Texas, USA

\section{Other Disciplines}

Dr. Aniruddha Belsare, Columbia MO 65203, USA (Veterinary)

Dr. Mandar S. Paingankar, University of Pune, Pune, Maharashtra, India (Molecular)

Dr. Jack Tordoff, Critical Ecosystem Partnership Fund, Arlington, USA (Communities)

Dr. Ulrike Streicher, University of Oregon, Eugene, USA (Veterinary)

Dr. Hari Balasubramanian, EcoAdvisors, Nova Scotia, Canada (Communities)

Dr. Rayanna Hellem Santos Bezerra, Universidade Federal de Sergipe, São Cristóvão, Brazil

Dr. Jamie R. Wood, Landcare Research, Canterbury, New Zealand

Dr. Wendy Collinson-Jonker, Endangered Wildlife Trust, Gauteng, South Africa

Dr. Rajeshkumar G. Jani, Anand Agricultural University, Anand, Gujarat, India

Dr. O.N. Tiwari, Senior Scientist, ICAR-Indian Agricultural Research Institute (IARI), New

Delhi, India

Dr. L.D. Singla, Guru Angad Dev Veterinary and Animal Sciences University, Ludhiana, India

Dr. Rupika S. Rajakaruna, University of Peradeniya, Peradeniya, Sri Lanka

Dr. Bahar Baviskar, Wild-CER, Nagpur, Maharashtra 440013, India

Reviewers 2018-2020

Due to pausity of space, the list of reviewers for 2018-2020 is available online.
The opinions expressed by the authors do not reflect the views of the Journal of Threatened Taxa, Wildlife Information Liaison Development Society, Zoo Outreach Organization, or any of the partners. The journal, the publisher, the host, and the partners are not responsible for the accuracy of the political boundaries shown in the maps by the authors.

\footnotetext{
Print copies of the Journal are available at cost. Write to:

The Managing Editor, JoTT,

c/o Wildlife Information Liaison Development Society,

No. 12, Thiruvannamalai Nagar, Saravanampatti - Kalapatti Road,

Saravanampatti, Coimbatore, Tamil Nadu 641035, India

ravi@threatenedtaxa.org
} 


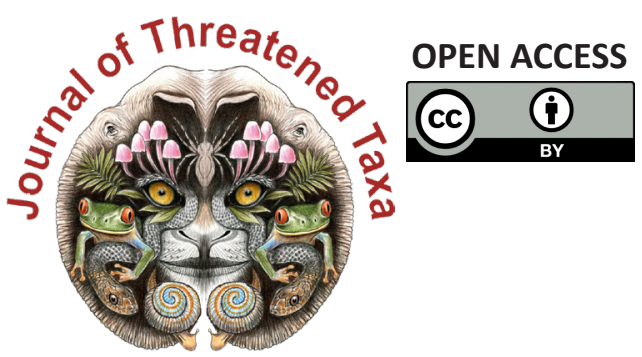

www.threatenedtaxa.org

The Journal of Threatened Taxa (JoTT) is dedicated to building evidence for conservation globally by publishing peer-reviewed articles online every month at a reasonably rapid rate at www.threatenedtaxa.org. All articles published in JoTT are registered under Creative Commons Attribution 4.0 International License unless otherwise mentioned. JoTT allows allows unrestricted use, reproduction, and distribution of articles in any medium by providing adequate credit to the author(s) and the source of publication.

\section{ISSN $0974-7907$ (Online) | ISSN $0974-7893$ (Print)}

\section{September 2021 | Vol. 13 | No. 11 | Pages: 19431-19674 Date of Publication: 26 September 2021 (Online \& Print) DOI: 10.11609/jott.2021.13.11.19431-19674}

Articles

Understanding human-flying fox interactions in the Agusan Marsh Wildlife Sanctuary as basis for conservation policy interventions

- Sherryl L. Paz \& Juan Carlos T. Gonzalez, Pp. 19431-19447

Argentinian odonates (dragonflies and damselflies): current and future distribution and discussion of their conservation

- A. Nava-Bolaños, D.E. Vrech, A.V. Peretti \& A. Córdoba-Aguilar, Pp. 19448-19465

\section{Communications}

The diel activity pattern of small carnivores of Western Ghats, India: a case study at Nelliampathies in Kerala, India

- Devika Sanghamithra \& P.O. Nameer, Pp. 19466-19474

Distribution and threats to Smooth-Coated Otters Lutrogale perspicillata (Mammalia: Carnivora: Mustelidae) in Shuklaphanta National Park, Nepal

- Gopi Krishna Joshi, Rajeev Joshi \& Bishow Poudel, Pp. 19475-19483

Wildlife hunting practices of the Santal and Oraon communities in Rajshahi, Bangladesh - Azizul Islam Barkat, Fahmida Tasnim Liza, Sumaiya Akter, Ashikur Rahman Shome \& M. Fazle Rabbe, Pp. 19484-19491

Ethnozoological use of primates in northeastern India

- Deborah Daolagupu, Nazimur Rahman Talukdar \& Parthankar Choudhury, Pp. 19492-19499

Factors influencing the flush response and flight initiation distance of three owl species in the Andaman Islands

- Shanmugavel Sureshmarimuthu, Santhanakrishnan Babu, Honnavalli Nagaraj Kumara \& Nagaraj Rajeshkumar, Pp. 19500-19508

Birds of Barandabhar Corridor Forest, Chitwan, Nepal

- Saneer Lamichhane, Babu Ram Lamichhane, Kapil Pokharel, Pramod Raj Regmi, Tulasi Prasad Dahal, Santosh Bhattarai, Chiranjibi Prasad Pokheral, Pabitra Gotame,

Trishna Rayamajhi, Ram Chandra Kandel \& Aashish Gurung, Pp. 19509-19526

On some additions to the amphibians of Gunung Inas Forest Reserve, Kedah,

Peninsular Malaysia

- Shahriza Shahrudin, Pp. 19527-19539

Reviews

A review of research on the distribution, ecology, behaviour, and conservation of the Slender Loris Loris lydekkerianus (Mammalia: Primates: Lorisidae) in India

- Mewa Singh, Mridula Singh, Honnavalli N. Kumara, Shanthala Kumar, Smitha D. Gnanaolivu \& Ramamoorthy Sasi, Pp. 19540-19552

Bivalves (Mollusca: Bivalvia) in Malaysian Borneo: status and threats

- Abdulla-Al-Asif, Hadi Hamli, Abu Hena Mustafa Kamal, Mohd Hanafi Idris, Geoffery James Gerusu, Johan Ismail \& Muyassar H. Abualreesh, Pp. 19553-19565

Disentangling earthworm taxonomic stumbling blocks using molecular markers

- Azhar Rashid Lone, Samrendra Singh Thakur, Nalini Tiwari, Olusola B. Sokefun \&

Shweta Yadav, Pp. 19566-19579

A reference of identification keys to plant-parasitic nematodes (Nematoda: Tylenchida) Tylenchomorpha)

- Reza Ghaderi, Manouchehr Hosseinvand \& Ali Eskandari, Pp. 19580-19602

Short Communications

Catalogue of herpetological specimens from Meghalaya, India at the Salim Ali Centre for Ornithology and Natural History

-S.R. Chandramouli, R.S. Naveen, S. Sureshmarimuthu, S. Babu, P.V. Karunakaran \&

Honnavalli N. Kumara, Pp. 19603-19610
A preliminary assessment of odonate diversity along the river Tirthan, Great Himalayan National Park Conservation Area, India with reference to the impact of climate change - Amar Paul Singh, Kritish De, Virendra Prasad Uniyal \& Sambandam Sathyakumar, Pp. 19611-19615

A checklist of orthopteran fauna (Insecta: Orthoptera) with some new records in the cold arid region of Ladakh, India

- M. Ali, M. Kamil Usmani, Hira Naz, Tajamul Hassan Baba \& Mohsin Ali, Pp. 19616-19625

New distribution records of two Begonias to the flora of Bhutan

- Phub Gyeltshen \& Sherab Jamtsho, Pp. 19626-19631

Rediscovery of Aponogeton lakhonensis A. Camus (Aponogetonaceae): a long-lost aquatic plant of India

- Debolina Dey, Shrirang Ramchandra Yadav \& Nilakshee Devi, Pp. 19632-19635

Glyphochloa acuminata (Hack.) Clayton var. laevis (Poaceae): a new variety from central Western Ghats of Karnataka, India

- H.U. Abhijit \& Y.L. Krishnamurthy, Pp. 19636-19639

A cytomorphological investigation of three species of the genus Sonchus L. (Asterales: Asteraceae) from Punjab, India

- M.C. Sidhu \& Rai Singh, Pp. 19640-19644

Dryopteris lunanensis (Dryopteridaceae) - an addition to the pteridophytic diversity of India

- Chhandam Chanda, Christopher Roy Fraser-Jenkins \& Vineet Kumar Rawat, Pp. 1964519648

Notes

First record of Spotted Linsang Prionodon pardicolor (Mammalia: Carnivora:

Prionodontidae) with photographic evidence in Meghalaya, India

- Papori Khatonier \& Adrian Wansaindor Lyngdoh, Pp. 19649-19651

First record of the Eastern Cat Snake Boiga gocool (Gray, 1835) (Squamata: Colubridae) from Tripura, India

- Sumit Nath, Biswajit Singh, Chiranjib Debnath \& Joydeb Majumder, Pp. 19652-19656

First record of the genus Tibetanja (Lepidoptera: Eupterotidae: Janinae) from India - Alka Vaidya \& H. Sankararaman, Pp. 19657-19659

Austroborus cordillerae (Mollusca: Gastropoda) from central Argentina: a rare, little-known land snail

- Sandra Gordillo, Pp. 19660-19662

Intestinal coccidiosis (Apicomplexa: Eimeriidae) in a Himalayan Griffon Vulture Gyps himalayensis

- Vimalraj Padayatchiar Govindan, Parag Madhukar Dhakate \& Ayush Uniyal, Pp. 1966319664

Two new additions to the orchid flora of Assam, India

- Sanswrang Basumatary, Sanjib Baruah \& Lal Ji Singh, Pp. 19665-19670

Wildlife art and illustration - combining black and white ink drawings with colour: some experiments in Auroville, India

- M. Eric Ramanujam \& Joss Brooks, Pp. 19671-19674
Publisher \& Host

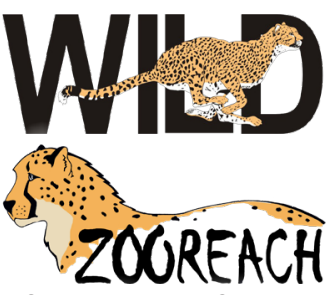

